\title{
MELATIH KETERAMPILAN BERPIKIR KRITIS MENGGUNAKAN METODE PEMBELAJARAN PENEMUAN TERBIMBING (GUIDED DISCOVERY) PADA SISWA SMP
}

\author{
Windarti ${ }^{1)}$ \\ Tjandrakirana $^{2)}$ \\ Widodo $^{2)}$ \\ 1)Mahasiswa Pascasarjana Prodi Pendidikan Sains Universitas Negeri Surabaya \\ 2)Dosen Pascasarjana Prodi Pendidikan Sains Universitas Negeri Surabaya \\ e-mail: lestya_windarti@yahoo.com
}

\begin{abstract}
The reality found in school showed that the teaching and learning experiences were dominated by the use of the Direct Instruction model and there were no activities to facilitate students to think criticaly. Thus, it is necessary to develop guided discovery learning materials to overcome it. The one group pretest-posttest design was used as a the research design involving 30 Junior High School students. The data were analyzed through descriptive qualitative technique. The results showed that students' activities were consistent with each stage of the guided discovery learning, students' responses were good, and N-gain test informed that the students' learning outcome and their capability to use critical thinking skills increased. Based on those findings, it can be concluded that the guided discovery instructional materials were effective to facilitate Junior High School students by think critically.
\end{abstract}

Keywords: critical thinking skill, guided discovery.

\begin{abstract}
Abstrak: Kenyataan di sekolah metode pembelajaran yang digunakan lebih berorientasi pada Direct Instruction dan belum tersedia perangkat pembelajaran yang dapat melatih keterampilan berpikir kritis siswa sehingga perlu dikembangkan pembelajaran yang berorientasi pada penemuan terbimbing untuk melatihkan keterampilan berpikir kritis kepada siswa SMP. Rancangan penelitian one group pretest-posttest design dengan subyek 30 orang siswa SMP. Data dianalisis secara deskriptif kualitatif. Hasil penelitian menunjukkan aktivitas siswa sesuai dengan tahapan penemuan terbimbing, respon siswa baik, uji $N$ Gain menunjukkan peningkatan hasil belajar dan kemampuan berpikir kritis serta pembelajaran penemuan terbimbing, pokok bahasan peran manusia dalam pengelolaan lingkungan efektif untuk melatihkan keterampilan berpikir kritis siswa SMP.
\end{abstract}

Kata Kunci: keterampilan berpikir kritis, penemuan terbimbin.

\section{PENDAHULUAN}

Pendidikan merupakan indikator penting untuk mengukur kemajuan suatu bangsa, jika suatu bangsa ingin ditempatkan pada tataran pergaulan dunia yang bermartabat dan modern, maka yang pertama-tama harus dilakukan adalah mengembangkan pendidikan yang memiliki relevansi dan daya saing bagi seluruh anak bangsa. IPA menurut Depdiknas (2008) merupakan studi mengenai alam sekitar, dalam hal ini berkaitan dengan cara mencari tahu tentang alam secara sistematis sehingga IPA bukan hanya penguasaan kumpulan pengetahuan yang berupa fakta-fakta, konsep-konsep atau prinsip-prinsip saja, tetapi juga merupakan suatu proses penemuan. Pembelajaran IPA diarahkan untuk mencari tahu dan berbuat, sehingga membuat siswa lebih aktif dalam mengembangkan sejumlah pengetahuan yang menyangkut keterampilan memecahkan masalah, pemahaman konsep, dan aplikasinya. Peran guru yang utama adalah membantu siswa menjadi pebelajar mandiri dengan cara menyajikan masalah yang kontekstual, kemudian membimbing siswa untuk mengajukan permasalahan dan memfasilitasi penyelidikan untuk memecahkan permasalahan tersebut secara mandiri. Salah satu tujuan utama kegiatan sekolah adalah meningkatkan kemampuan siswa untuk berpikir kritis, membuat keputusan rasional tentang apa yang diperbuat atau apa yang diyakini (Ennis, 1989; Hitchcock, 1983 dalam Nur dan Wikandari, 2008). Sekolah seharusnya mengajarkan dan memberdayakan keterampilan berpikir siswa, karena dengan memberdayakan keterampilan berpikir diyakini berpotensi besar memberdayakan manusia (Wikandari, 2008). Menghafal bukan lagi cara jitu untuk menjadikan siswa mendapatkan hasil belajar yang baik, berdasarkan hasil survey internasional PISA siswa sekolah yang berusia 15 tahun di Indonesia kemampuan SAINS-nya masih peringkat 10 besar terbawah dari 65 negara peserta (Puspendik, 2012).

Kenyataan yang ditemukan di SMP Katolik Santa Clara menunjukkan bahwa proses pembelajaran yang dilakukan masih di dominasi oleh guru dan belum 
memberikan akses bagi siswa untuk berkembang secara mandiri melalui proses penemuan, alasan yang dikemukakan oleh guru adalah keterbatasan waktu, sarana, lingkungan belajar dan jumlah peserta didik yang terlalu banyak. Kondisi ini akan menimbulkan kejenuhan pada siswa sehingga kurang termotivasi dalam proses belajar dan kurang dapat meningkatkan aktivitas serta kreativitasnya, akibatnya siswa menjadi pasif, meskipun demikian guru lebih suka menerapkan model tersebut, cukup menjelaskan konsep-konsep yang ada pada buku ajar atau referensi lain. Siswa tidak diajarkan strategi belajar yang dapat memahami bagaimana belajar, berpikir dan memotivasi diri sendiri, pembelajaran biologi yang dilakukan lebih dominan kepada aspek pengetahuan dan pemahaman konsep, akibatnya keterampilan berpikir kritis dikalangan siswa tidak dapat bertumbuh kembang sesuai dengan harapan (Adnyana,

2009).

Kurikulum Tingkat Satuan Pendidikan (KTSP) menuntut perubahan paradigma dalam pendidikan dan pembelajaran, khususnya pada jenis dan jenjang pendidikan formal, berlakunya KTSP menghendaki bahwa suatu pembelajaran pada dasarnya tidak hanya mempelajari tentang konsep, teori dan fakta, tetapi juga aplikasi dalam kehidupan sehari-hari. Guru harus bijaksana dalam menentukan suatu model pembelajaran agar dapat menciptakan situasi dan kondisi kelas yang kondusif dan proses belajar mengajar dapat berlangsung sesuai dengan tujuan yang diharapkan, khususnya dalam pelaksanaan Kurikulum 2013 yang akan datang yaitu mempersiapkan manusia Indonesia agar memiliki kemampuan hidup sebagai pribadi dan warga negara yang beriman, produktif, kreatif, inovatif, dan afektif serta mampu berkontribusi pada kehidupan bermasyarakat, berbangsa, bernegara dan peradaban dunia. Kecakapan hidup yang dibekalkan itu diyakini dapat digunakan untuk menghadapi tantangan kehidupan secara mandiri, cerdas, kritis, rasional, dan kreatif. Salah satu kecakapan hidup yang dikembangkan melalui pembelajaran IPA adalah keterampilan berpikir kritis.

Keterampilan berpikir siswa dalam proses

pembelajaran merupakan suatu kemampuan yang sangat penting. Berbagai kajian telah menemukan adanya hubungan antara keterampilan penalaran formal dan prestasi belajar biologi termasuk keterampilan laboratorium dan keterampilan berpikir kritis (Corebima, 1999). Menurut Gadzella, Ginther, \& Bryant (1997) dalam Nurmaliah, (2009) selama tingkat berpikir kritis rendah akan berpengaruh terhadap keberhasilan dalam area-area yang memerlukan berpikir kritis. Preisseisen (1982) dalam Nurmaliah, (2009) menyatakan di sekolah menengah pertama merupakan saat yang tepat untuk awal mengajarkan keterampilan tingkat tinggi atau proses berpikir kompleks, karena perkembangan kapasitas kognitif siswa remaja telah matang untuk diberikan tantangan berupa berpikir lebih kompleks. Mengajarkan atau melatihkan keterampilan berpikir dapat membantu siswa untuk menjadi pemikir yang kritis secara efektif.

Menurut Wilcox dalam Nur (2008) bahwa pembelajaran dengan metode penemuan dapat mendorong siswa untuk belajar, sebagian besar melalui keterlibatan aktif mereka sendiri dengan konsep-konsep dan prinsip-prinsip, serta pengalaman dalam melakukan percobaan yang memungkinkan mereka menemukan prinsip-prinsip untuk diri mereka sendiri.

Metode penemuan terbimbing (Guided Discovery Learning) memiliki kelebihan dalam hal melibatkan siswa aktif pada proses pembelajaran yang mampu memicu kemampuan berpikir siswa setiap saat dalam KBM, sehingga metode ini lebih sesuai untuk melatih keterampilan berpikir kritis siswa pada tingkat sekolah

dasar dan sekolah menengah pertama. Kurikulum IPA SMP memiliki beberapa materi ajar yang dapat digunakan untuk melatih keterampilan berpikir kritis, salah satu diantaranya adalah materi pencemaran dan kerusakan lingkungan, terutama untuk mencapai Kompetensi Dasar (KD) "Mengaplikasikan peran manusia dalam pengelolaan lingkungan untuk mengatasi pencemaran dan kerusakan lingkungan". Kompetensi Dasar tersebut mengulas tentang pencemaran dan dampak negatif yang ditimbulkan, sehingga pada materi ini dapat dijumpai beberapa permasalahan dalam kehidupan sehari-hari, dengan demikian siswa diharapkan dapat melatih kemampuan berpikir kritisnya dalam mencari solusi dari permasalahan yang dijumpai. Guru sebagai fasilitator, diharapkan dapat menyajikan permasalahan bagi siswa sesuai dengan materi untuk melatih keterampilan berpikir kritis, hal ini sesuai dengan pendapat Dult (1997) yang menyatakan bahwa pembelajaran yang dapat meningkatkan kemampuan berpikir kritis adalah melalui belajar berdasarkan masalah dalam kehidupan sehari-hari. Sependapat dengan hal tersebut, pembelajaran dengan penemuan terbimbing dapat membantu siswa untuk mengembangkan keterampilan berpikir, mengatasi masalah, mempelajari peran-peran orang dewasa dan menjadi pelajar yang mandiri (Arends, 2008).

Berkaitan dengan paparan tersebut, masalah yang terdapat di sekolah yang diteliti adalah belum ada perangkat pembelajaran dengan metode penemuan terbimbing terkait peran manusia dalam pengelolaan lingkungan yang dikembangkan untuk melatih kemampuan berpikir kritis. Beberapa alasan yang menyebabkan hal tersebut, diantaranya: (1) terbatasnya 
pengetahuan akan model pembelajaran inovatif pada beberapa guru, khususnya bidang studi IPA, (2) keterbatasan waktu guru mata pelajaran IPA untuk menyediakan perangkat pembelajaran yang dapat melatih kemampuan berpikir kritis. Hal inilah yang menjadi pendorong untuk mengkaji lebih lanjut.

Berdasarkan latar belakang di atas, maka dilakukan penelitian dengan judul "Melatih Keterampilan Berpikir Kritis Menggunakan Metode Pembelajaran Penemuan Terbimbing (Guided Discovery Learning) pada Siswa SMP" dengan menggunakan perangkat pembelajaran yang telah dikembangkan meliputi Rencana Pelaksanaan Pembelajaran (RPP), Lembar Kerja Siswa (LKS), Materi Ajar Siswa (MAS), Lembar instrumen tes terkait dengan tes keterampilan berpikir kritis dan tes hasil belajar.

\section{METODE}

Penelitian ini merupakan jenis penelitian eksperimen semu dengan menerapkan perangkat pembelajaran yang telah dikembangkan. Model yang digunakan untuk merancang pengembangan perangkat pembelajaran adalah model Dick and Carey yang dimodifikasi sesuai kebutuhan. Rancangan pengembangan perangkat pembelajaran dalam penelitian ini adalah sebagai berikut:

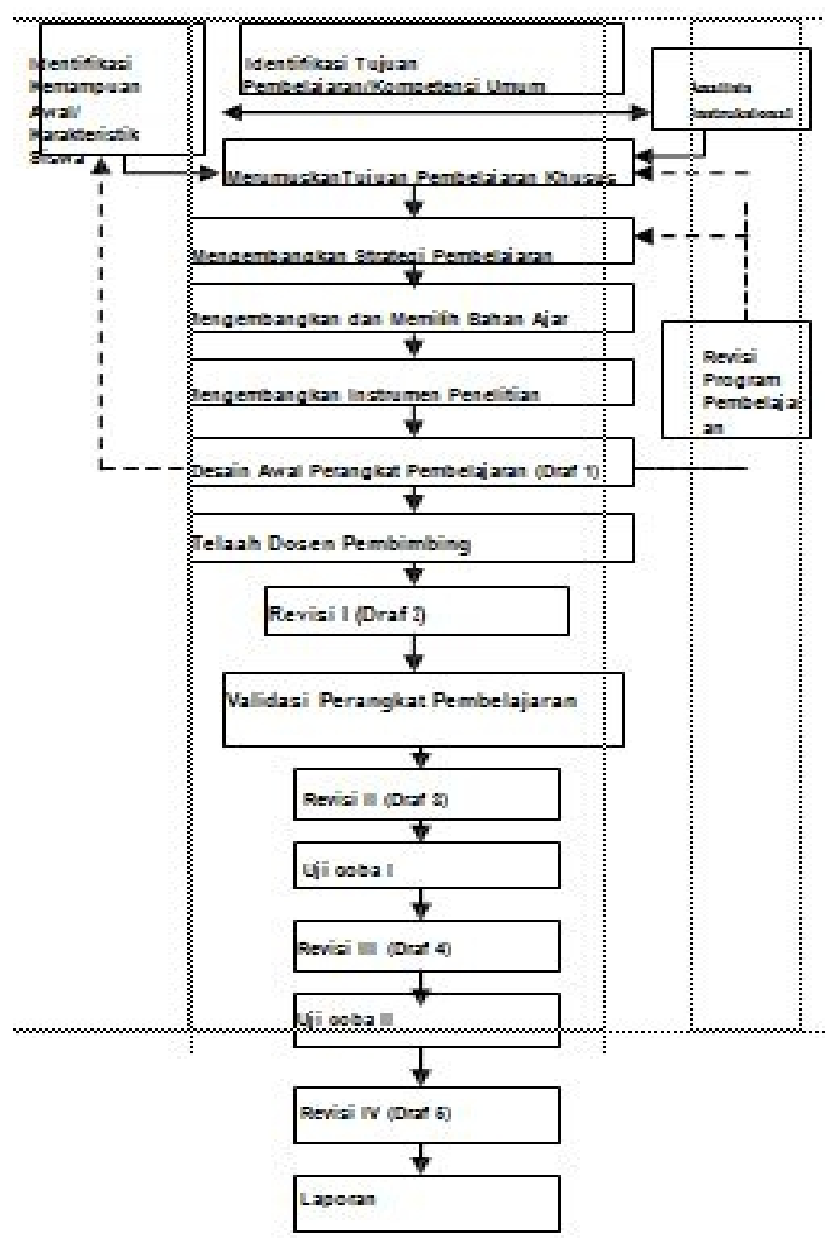

Gambar 1. Diagram alir tahapan pengembangan perangkat (Diadaptasi dari Dick and Carey (2009: 3)).
Ujicoba penelitian ini dilakukan pada 30 siswa kelas VII SMP Katolik Santa Clara Surabaya. Implementasi dengan menggunakan rancangan penelitian One-Group Pretest- Postest Design, karena penelitian ini hanya menggunakan satu kelompok saja tanpa adanya kelompok pembanding. Instrumen penelitian ini kemudian di validasi oleh tiga pakar pendidikan. Teknik pengambilan data pada penelitian ini adalah dengan observasi, tes dan angket. Materi yang dikembangkan adalah 1) lingkungan, 2) pencemaran lingkungan, 3) kerusakan lingkungan, 4) pengelolaan lingkungan.

\section{HASIL DAN PEMBAHASAN}

\section{A. Aktiviitas Siswa}

Aktivitas siswa dalam kegiatan pembelajaran pada penelitian ini telah mencerminkan aktivitas yang sesuai dengan tahap-tahap pembelajaran penemuan terbimbing dengan presentase aktivitas mendengarkan penjelasan guru 9.79\%, membaca LKS $10.0 \%$, merumuskan hipotesis $10.0 \%$, mengidentifikasi variabel eksperimen $10.0 \%$, melaksanakan eksperimen $10.0 \%$, mengumpulkan data $10.0 \%$, menganalisis data $10.0 \%$, mempresentasikan hasil eksperimen $10.0 \%$, dan menanggapi presentasi kelompok $10.0 \%$. Aktivitas siswa merancang prosedur eksperimen $8.54 \%$. Perhatian siswa untuk mengikuti proses pembelajaran cukup tinggi. Hal ini dapat disimpulkan bahwa siswa antusias dalam mengikuti proses pembelajaran. Antusiasme siswa dalam pembelajaran merupakan salah satu efek dari penggunaan metode pembelajaran penemuan terbimbing yang merupakan metode pembelajaran yang baru bagi siswa. Aktivitas siswa dalam RPP dirancang untuk melakukan eksperimen yang digunakan untuk membuktikan hipotesis, sehingga aktivitas yang paling dominan adalah aktivitas eksperimen. Hal ini dilakukan karena eksperimen ini merupakan kunci dari aktivitas penemuan terbimbing, dengan penemuan terbimbing siswa harus membangun sendiri pengetahuan di dalam benaknya dengan bantuan guru dan didorong untuk belajar melalui keterlibatan aktif yang memungkinkan mereka menemukan fakta dan konsep bagi diri mereka sendiri sehingga fakta dan konsep tersebut menjadi bermakna bagi mereka (Nur, 2011).

Diskusi yang dilakukan siswa untuk menganalisis data dan menanggapi presentasi dari kelompok lain, hal ini mencerminkan keterampilan sosial berkomunikasi siswa meningkat. Diskusi ini mempunyai peran penting dalam pemahaman konsep siswa, dengan diskusi pada setiap kelompok dapat membantu anggota kelompok yang belum sepenuhnya memahami konsep yang dipelajari,. dengan cara ini sebenarnya siswa belajar melalui interaksi dengan teman sebaya sehingga siswa dengan kemampuan tinggi akan terbuka untuk membantu siswa lain dan terjadi proses 
belajar yang lebih mudah (Nur, 2011).

Kesesuaian antara metode dengan aktivitas siswa tidak lepas dari keterlaksanaan tahap-tahap pembelajaran yang telah dirancang, terlaksananya tahap-tahap pembelajaran dengan baik sangat mempengaruhi aktivitas siswa dalam pembelajaran. Aktivitas siswa yang paling dominan adalah aktivitas eksperimen, hal ini sangat relevan karena metode penemuan terbimbing yang digunakan memang menekankan pada proses pemerolehan pemahaman konsep melalui pengamatan/ eksperimen yang dilakukan sendiri oleh siswa. Metode pembelajaran penemuan terbimbing mengajak siswa untuk belajar memahami materi peran manusia dalam pengelolaan lingkungan melalui proses eksperimen, dengan melakukan eksperimen siswa akan membangun pemahaman dan pengetahuan baru dari konsep yang mereka pelajari. Persentase pengamatan/ eksperimen siswa yang tinggi menunjukkan siswa melaksanakan aktivitas tersebut dengan baik, sehingga dimungkinkan siswa akan mendapat pemahaman yang utuh terhadap konsep yang dipelajari.

\section{B. Respons Siswa Terhadap Kegiatan Pembelajaran}

Respons siswa terhadap kegiatan pembelajaran diketahui dari data hasil pengisian angket setelah mengikuti pembelajaran. Siswa tertarik mengikuti pembelajaran penemuan terbimbing, hal ini ditunjukkan oleh respon siswa terhadap materi pelajaran, LKS, materi ajar siswa, suasana belajar, cara guru mengajar, dan tahapan-tahapan yang diarahkan guru dalam proses pembelajaran, dari tabel diperoleh bahwa $100 \%$ siswa tertarik dengan materi yang diajarkan. Tingginya ketertarikan siswa terhadap materi sangat wajar, karena materi yang diajarkan berkaitan erat dengan kehidupan sehari-hari siswa, meskipun materi pernah diajarkan pada tingkat SD, tetapi materi yang diajarkan di SMP lebih kompleks. Ketertarikan siswa pada MAS dan LKS memiliki persentase $100 \%$ dan $80 \%$ hal ini menunjukkan bahwa siswa tertarik menggunakan Materi Ajar Siswa dan LKS untuk memahami konsep yang mereka pelajari. Suasana belajar yang menyenangkan akan membuat siswa dapat menerima pelajaran dengan baik, berdasarkan data diperoleh bahwa suasana belajar yang terjadi selama pembelajaran sangat menarik bagi siswa, terbukti $90 \%$ siswa menyatakan tertarik.

Hal ini mengindikasikan bahwa penggunaan metode pembelajaran penemuan terbimbing membuat siswa antusias mengikuti pelajaran.

Cara mengajar guru mendapat respons positif dari siswa, sebanyak $100 \%$ siswa tertarik dengan cara guru mengajar, hal ini menunjukkan bahwa tahapan pembelajaran dengan metode penemuan terbimbing menarik bagi siswa dan memberi respon positif, dengan demikian diharapkan hasil belajar terutama pemahaman konsep siswa meningkat. Data respon siswa juga menunjukkan bahwa pembelajaran dengan metode penemuan terbimbing memiliki kesulitan yang cukup tinggi terutama dalam menganalisis data, persentase menentukan variabel manipulasi, variabel kontrol, variabel respon, dan menganalisis data masing- masing $80 \%, 80 \%, 70 \%$, dan $40 \%$, meskipun memiliki kesulitan terhadap komponen menganalisis data, para siswa sangat berminat dengan pembelajaran penemuan terbimbing ini, hal itu terlihat dari data $100 \%$ siswa berminat mengikuti pembelajaran dengan metode penemuan terbimbing. Siswa sangat memerlukan bimbingan guru untuk mengatasi kesulitan tersebut. Metode pembelajaran penemuan terbimbing tidak selamanya baik untuk setiap pembelajaran, bergantung pada karakteristik materi yang disampaikan, sehingga meskipun siswa tertarik pada penggunaan model pembelajaran penemuan terbimbing, guru harus melihat karakteristik materi yang akan disampaikan.

Secara keseluruhan, siswa memberikan respons positif terhadap pembelajaran, respons positif ini menunjukkan bahwa siswa antusias dengan pembelajaran yang disajikan. Hal ini dapat memotivasi siswa untuk meningkatkan perhatian dan membuat mereka terlibat dalam pengalaman pembelajaran yang menyenangkan dan bermakna (Nur, M. 2008).

\section{Tes Hasil Belajar}

Hasil analisis pretest dan posttest untuk hasil belajar yang menunjukkan bahwa nilai rata-rata mengalami peningkatan. Kriteria Ketuntasan Minimal SMP Katolik Santa Clara menetapkan standar ketuntasan minimal 75. Pada penelitian ini ketuntasan klasikal mencapai 96,6 \% dan diperoleh sensitivitas butir soal rata-rata antara 0.3-1. Hal ini menunjukkan bahwa semua butir soal peka terhadap efek pembelajaran.

Analisis sensitivitas tes hasil belajar menunjukkan sensitivitas butir soal berkisar antara 0,30 sampai 0,67 dan berharga positif sehingga dapat dikatakan bahwa setiap butir soal sensitif untuk mengukur pembelajaran. Menurut Gronlund (1982) indeks sensitivitas suatu butir soal berkisar antara 0,3-1 semakin besar harga sensitivitasnya, semakin besar kepekaan butir soal terhadap efek pembelajaran. Oleh karena itu, butir- butir soal THB yang digunakan pada uji awal dan uji akhir dapat digunakan untuk mengukur efek pembelajaran.

Pada uji akhir dari 29 siswa secara individu mempunyai nilai $\geq 75$ sehingga $96.6 \%$ dari jumlah siswa dapat dinyatakan telah melampaui batas kriteria ketuntasan minimal yang berlaku di SMP Katolik Santa Clara Surabaya. Hal ini disebabkan pada uji akhir siswa sudah menerima materi pelajaran sehingga siswa menjadi tahu 
dan paham tentang materi peran manusia dalam pengelolaan lingkungan, oleh karena itu siswa lebih mudah untuk mengerjakan soal dan hasil belajar siswa meningkat. Penggunaan metode pembelajaran penemuan terbimbing dapat memberikan motivasi-motivasi untuk tetap antusias dalam mengikuti pelajaran hingga akhir, namun perlu dilatihkan secara terus menerus dan dilakukan untuk semua pelajaran dengan materi pelajaran yang sesuai. untuk ketuntasan hasil belajar sudah termasuk tinggi karena hanya satu siswa saja yang tidak tuntas. Keterlibatan guru menciptakan komunitas kelas yang hangat dan penuh perhatian dengan banyaknya praktik merupakan motivasi yang suportif, dan selalu menunjukkan perencanaan yang baik mengakibatkan hasil kerja siswa mencapai tingkat yang tinggi (Arends, 2008), dalam pembelajarannya siswa didorong untuk terlibat aktif dalam menemukan pengetahuannya dengan kegiatan yang bervariasi seperti melakukan pengamatan, percobaan, dan membaca. Siswa didorong untuk belajar dengan terlibat aktif melalui konsep- konsep dan prinsip-prinsip, dan guru mendorong siswa untuk memiliki pengalaman dan melakukan percobaan yang memungkinkan mereka menemukan konsep-konsep untuk diri mereka sendiri (Brunner 1996, dalam Nur 2008).

\section{Keterampilan Berpikir Kritis}

Hasil analisis statistik N-Gain rata-rata dari 30 siswa untuk indikator I (merumuskan masalah) adalah 0.49, indikator II (memberikan argumentasi) sebesar 0.80 , indikator III (melakukan analisis) 0.73, indikator IV (melakukan evaluasi) 0.81, dan indikator V (memutuskan dan melaksanakan) sebesar 0.67. N-Gain rata-rata indikator berpikir kritis menjelaskan bahwa peningkatan hasil tes keterampilan berpikir kritis siswa berada pada kriteria sedang (di antara 0.3 dan 0.7) untuk indikator I dan V, sedangkan untuk indikator II, III dan IV memiliki kriteria tinggi (lebih dari 0.7) berdasarkan kriteria N- Gain yang ditetapkan oleh Hake (1999). Hasil analisis menunjukkan bahwa indikator-indikator keterampilan berpikir kritis yang diteliti memiliki kriteria N-Gain sedang dan tinggi, hal ini disebabkan siswa berminat dengan kegiatan pembelajaran metode penemuan terbimbing. Berdasar respon siswa juga diperoleh data bahwa pembelajaran dengan metode penemuan terbimbing menarik, merupakan hal baru dan siswa senang. Aktivitas yang dominan dilakukan selama proses pembelajaran berlangsung mulai dari pertemuan pertama, kedua, sampai pada pertemuan ketiga adalah aktivitas menguji hipotesis dengan eksperimen dan menganalisis data, pada tiap pertemuan siswa melakukan percobaan untuk menyelidiki hipotesis yang sudah dirumuskan, sebelum percobaan siswa dibimbing untuk menemukan variabel eksperimen terlebih dahulu, pemahaman konsep didapat melalui kesimpulan berdasar analisa data, sedangkan untuk melatih pemahaman konsep maka LKS dilengkapi pertanyaan untuk didiskusikan yang selanjutnya dipresentasikan oleh siswa.

Hasil analisis N-Gain dalam penelitian ini menggambarkan bahwa metode pembelajaran penemuan terbimbing mampu melatihkan keterampilan berpikir kritis siswa, karena hasil yang diperoleh berada pada kategori tinggi dan sedang dengan N-Gain rata-rata 0.62 .. Kategori tinggi dapat diperoleh dengan sering melatihkan keterampilan berpikir kritis pada siswa. Hasil penelitian sensitivitas setiap butir soal menunjukkan bahwa sensitivitas butir soal untuk no 1 sampai 10 berada di antara 0.3 sampai dengan 1 berarti termasuk kategori peka terhadap efek pembelajaran.

\section{TEMUAN}

Berdasarkan hasil analisa data dan pembahasan penelitian yang dikaitkan dengan pertanyaan penelitian diperoleh temuan penelitian sebagai berikut:

1. Aktifitas siswa termasuk pada kategori baik.

2. Respon siswa sebagian besar menyatakan kegiatan pembelajaran menarik untuk diikuti.

3. Hasil belajar siswa mengalami peningkatan setelah diterapkan metode pembelajaran penemuan terbimbing.

4. Keterampilan berpikir kritis siswa mengalami peningkatan setelah diterapkan metode penemuan terbimbing.

\section{PENUTUP \\ Simpulan}

Berdasarkan hasil analisis data dan pembahasan maka dapat disimpulkan bahwa pembelajaran dengan menggunakan metode penemuan terbimbing efektif untuk melatihkan keterampilan berpikir kritis kepada siswa SMP pada materi Peran Manusia dalam Pengelolaan Lingkungan.

\section{Saran}

Berdasarkan penelitian yang telah dilakukan dan hasil yang didapat, disarankan beberapa hal sebagai berikut:

1. Guru hendaknya mengembangkan dan menerapkan perangkat pembelajaran dengan metode penemuan terbimbing dalam kegiatan pembelajaran untuk materi yang lain.

2. Guru memberikan bimbingan lebih pada saat siswa melakukan percobaan, khususnya pada tahap membuat definisi operasional variabel dan menganalisis data.

3. Sekolah sudah semestinya melatihkan keterampilan berpikir kritis dengan memberi pengalaman-pengalaman bermakna saat proses belajar mengajar. 


\section{DAFTAR PUSTAKA}

Afandi. 2009. Dampak polusi terhadap Kesehatan Manusia. Diakses melalui http://dahlanforum.wordpress.com/2009/07/07/dampa k-polusi-terhadap-kesehatan-manusia/ pada tanggal 20 Februari 2011.

Agustina, K.D. 2010. Vegetasi Pohon di Hutan Lindung. Malang: UIN-Maliki Press.

Anderson, L.W. and David, R.K.. 2006. A Revision of Bloom's Taxonomy of Educational Objectives, A bridged Edition. New York: Longman.

Arends, R. I. 2008. Learning To Teach, Belajar untuk Mengajar. Edisi Ketujuh Yogyakarta: Pustaka Pelajar.

Arends, Richard. 1997. Learning to Teach: Fifth Edition. New York: McGraw Hill. Inc.

Arifin, Z. 2010. Evaluasi Pembelajaran Prinsip, Teknik dan Prosedur. Bandung: Remaja Rosdakarya.

Arikunto, S. 2010. Dasar- dasar Evaluasi Pendidikan Edisi Revisi. Jakarta: Bumi Aksara.

Adnyana, G. P. 2009. "Meningkatkan Kualitas Aktifitas Belajar, Keterampilan Berpikir Kritis, dan Pemahaman Konsep Biologi Siswa Kelas X-5 SMA Negeri 1 Banjar Melalui Penerapan Model Pembelajaran Berbasis Masalah" Jurnal Pendidikan Kerta Mandala Vol. 1 No. 001. Oktober 2009 . pp 15 ISSN 2085-9716.

Arnyana, I. B. P. 2004."Pengaruh Penerapan Model PBL Dipandu Strategi Kooperatif Terhadap Kecakapan Berpikir Kritis Siswa SMA Pada Mata Pelajaran Biologi” Artikel http://repository.upi.edu/operator/upload/s d025 033222 chapter2.pdf. Diakses 19 November 2011. Arnyana, I. B. P. 2006. "Pengaruh Penerapan Strategi

Pembelajaran Inovatif pada Pelajaran Biologi Terhadap Kemampuan Berpikir Kreatif Siswa SMA "Jurnal Pendidikan dan Pengajaran IKIP Negeri Singaraja No.3 Th XXXIX. Juli 2006.

Badan Standar Nasional Pendidikan. 2006. Standar Isi untuk Satuan Pendidikan Dasar dan Menengah. Jakarta: BSNP.

Barhydt, F.B 1989. Science Discovery Activities Kit. West Nyack. New York: The Center For Aplied Research in Education.

BSNP, 2006.Panduan Penyusunan Kurikulum Tingkat Satuan Pendidikan Jenjang Pendidikan Dasar dan Menengah, Jakarta: BSNP.

Carin, A. 1993. Teaching Science Through Discovery Seventh

Edition. New York: Macmillan Publishing Company. Castronova, J. A. 2002. Discovery Learning for the 21st Century:What is it and how does it compare to traditional learning in the 21st Century, http://chiron.valdosta.edu/are/

Litreviews/vol1no1/castronova ltr. pdf.

Cheung W.S. 2008. Online Discussion and Critical Thinking Skills: A case study in Singapore secondary schools. Australasian Journal of Educational Technology. $\quad 24 \quad$ (5): $\quad$ 556-573. Http://www.ascilite.org.au/ajet24/cheong.pdf.diakses 20 Desember 2011

Corebima, A. D. 1999. Proses dan Hasil Pembelajaran MIPA di SD, SLTP, dan SMU: "Perkembangan Penalaran Siswa Tidak Dikelola Secara Terencana" (Studi Kasus di Malang, Yogjakarta, dan Bandung) Proceeding Seminar on Quality Improvement of Mathematic and Science Education in Indonesia. Bandung. August. 2011.

Dahar, R.W. 1988. Teori-teori Belajar. Jakarta: Depdikbud.

Dick, W. and Carey, L. 2009. The Systematic Design of Instruction. Unite States of America: Foresman and Company.

Depdiknas. 2006. Peraturan Menteri Pendidikan Nasional No.22 Tahun 2006 tentang Standar Isi. Jakarta: Depdiknas.

Depdiknas. 2008. Strategi Pembelajaran MIPA. Jakarta: Direktorat Tenaga Kependidikan, Direktorat Jenderal Peningkatan Mutu Pendidik dan Tenaga Kependidikan, Departemen Pendidikan Nasional.

Dult, B.W. 1997. Coaching Winner: How to Teach Critical. (Online) http://www.kenetro.cc.mo.us/longviev/ctac/winners,ht m. Diakses 4 April 2010.

Ennis, R.H. 1985. Goals for a Critical Thinking Curriculum.

Dalam A.L. Costa (Ed.). Developing Minds: A Resource Book for Teaching Thinking. Virginia: Assosiation for Supervisions and Curriculum Development (ASCD).

Ennis, R. 1992. Critical Thinking: What is it? Proceeding of the Forty-Eight Annual Meeting of the Philosophy of Education Society: Denver.

Ennis, R. H. 1996. Critical Thinking. USA: Prentice-Hall, Inc. Effendi, H. 2003. Telaah Kualitas Air Bagi Pengelolaan Sumber Daya dan Lingkungan Perairan. Yogjakarta: Kanisius.

Fadilah, H. 2010. Pencemaran Suara. (Online) http://harrisfadilah.wordpress.com/2010/11/28/pence mar an-suara, Diakses 4 Pebruari 2012.

Fisher Alec. 2009. Berpikir Kritis. Jakarta: PT. Gelora Aksara, Pratama.

Gronlund, N.E. and Robert, L.L. 1982. Constructing Achievment Test. USA: Prentice-hall, Inc.

Hake, R.R. 1999.American Educational Research 
Association's Division D, Measurement and Research Methodology:Analyzing Change/Gain Scores. USA: Woodland Hills.

Handayani, L. Y. 2011. "Pemberdayaan Keterampilan Berpikir Kritis Melalui Pembelajaran Fisika dengan Pendekatan Keterampilan Proses". Tesis Magister Pendidikan, Universitas Negeri Surabaya.

Ibrahim, M dan M. Nur. 2000. Pengajaran Berbasis Masalah. Surabaya: Unesa University Press.

Ibrahim, M. 2001. Pengembangan Perangkat Pembelajaran (Pelatihan Terintegrasi Berbasis Kompetensi Guru Mata Pelajaran Biologi). Jakarta: Ditjen Dikdasmen Depdiknas.

Ibrahim, M. 2003. Pengembangan Perangkat Pembelajaran. Jakarta: Depdiknas.

Ibrahim, M. 2005. Asesmen Berkelanjutan. Surabaya: Unesa University Press.

Indriyanto. 2010. Ekologi Hutan. Jakarta: Bumi Aksara.

Irwan, Z. D. 2003. Ekosistem, Komunitas dan Lingkungan. Jakarta: Bumi Aksara.

Johnson, D. W. \& Johnson, R. T. 2002. Meaningful Assessment.A Manageable and Cooperative Process. Boston: Allyn \& Bacon.

Johnson, E.B. 2002. Contextual Teaching \& Learning. Meningkatkan Kegiatan Belajar Mengajar Mengasyikkan dan Bermakna. Jakarta: MLC.

Jufri, W. A. 2007. “ Pengaruh Implementasi Perangkat Pembelajaran Berbasis Inkuiri (PPBI) dengan strategi Kooperatif terhadap Keterampilan Berpikir Kritis, Sikap, dan Hasil Belajar Kognitif Siswa SMA Negeri di Kota Mataram”. Disertasi Doktoral, Universitas Negeri Malang.

Karim, Asrul. 2011. "Penerapan Metode Penemuan Terbimbing dalam Pembelajaran Matematika Untuk meningkatkan Kemampuan Berpikir Kritis Siswa Sekolah Dasar" Jurnal No. 1. ISSN 1412-565X.

Kementrian Pendidikan dan Kebudayaan Universitas Negeri Surabaya Program Pascasarjana. 2012. Pedoman Penulisan Tesis dan Disertasi. Surabaya: Program Pascasarjana Universitas Negeri Surabaya.

Kemp, J. E., Morrison, G. R., and Ross, S. M. 1994.Designing Effective Instruction. United States of America: Macmilan Collage Publishing Company.

Khaeruddin. 2011. “ Mengembangkan Karakter Tanggung Jawab dan Kemampuan Akademik Siswa melalui Pendekatan Pembelajaran Penemuan (Discovery Learning)". Tesis Magister Pendidikan, Universitas Negeri Surabaya.

Khasnis, B. Y. \& Aithal, M. 2011.” Guided Discovery Method Remedial Measure In Mathematics", International Referred Research Journal, July, 2011,
ISSN-0975-3486, RNI: RAJBIL 2009/30097, VolII*ISSUE 22. www.Docs-Finder.com. Diakses tanggal 12 Oktober 2011.

Krulik, S. and Rudnik, J.A.1996. The New Source Book for Teaching Reasoning and Problem Solving in Elementary School. Massachussets: Allyn and Bacon.

Liliasari. 2000. "Model Pembelajaran untuk Meningkatkan Keterampilan Berpikir Konseptual Tingkat Tinggi Calon Guru IPA". Dalam Proceeding Nasional Science Education Seminar, The Problem of Mathematics and Science Education and Alternative to Solve the Problems. Malang: JICAIMSTEP FMIPA UM.

Muhfahroyin. 2009. "Memberdayakan Kemampuan Berpikir Kritis". Sumber: http://muhfahroyin.blogspot.com /2009/01/berpikirkritis.html.

Mulyasa. 2006. Kurikulum Tingkat Satuan Pendidikan. Bandung: Rosda Karya.

Mustapha, R. 2005. "Kajian tentang Kemahiran Berpikir Kritis dan Kreatif (KBKK) dalam Pengajaran dan Pembelajaran Bahasa Melayu" Sm. Panitia Kesusastraan Melayu. Jemaah Nasir Sekolah Kementrian Pendidikan Online. Http://www.ipbl.edu.My/intern/penyelidikan/1998/98 _R afiei.pdf, diakses tanggal 20 Desember 2011.

Ningwidi, S. A. 2010.'Pengembangan Perangkat Pembelajaran Berdasarkan Pendekatan Penemuan Terbimbing untuk Melatihkan Keterampilan Berpikir Siswa Sekolah Dasar". Tesis Magister Pendidikan, Universitas Negeri Surabaya.

Nurlita, F. 2008. "Penggunaan Perangkat Pembelajaran Berdasarkan Masalah Untuk Meningkatkan Pemahaman Konsep Dan Mengembangkan Keterampilan Berpikir Kritis".JIPP, Juni 2008. pp. 885-901 .www.Pdf.com . Diakses tanggal 12 Oktober 2011.

Nur, M. 2004. Teori-teori Perkembangan Kognitif. Edisi 2.

Surabaya: Pusat Sains dan Pendidikan Matematika Sekolah Universitas Negeri Surabaya.

Nur, M \&Wikandari, P. R. 2008. Pengajaran Berpusat Kepada Siswa dan Pendekatan Konstruktivis dalam Pengajaran. Surabaya: Pusat Sains dan Pendidikan Matematika Sekolah Universitas Negeri Surabaya.

Nur, M. 2010. Strategi-strategi Belajar. Pusat Sains dan Matematika Sekolah: Universitas Negeri Surabaya.

Nur, M. 2011. Modul Keterampilan-keterampilan Proses Sains.

Disadur dari Inquiry Skills Activity Book. Pusat Sains dan Matematika Sekolah: Universitas Negeri Surabaya. 
Nurmaliah, C. 2009. Kemampuan Berpikir Kritis, Metakognisi, dan Hasil Belajar Biologi Peserta Didik SMP Negeri di Kota Malang. Disertasi tidak diterbitkan. Malang: Program Pasca Sarjana Pendidikan Biologi UM.

Pierce, W. 2009. Designing Rubrics for Assessing Higher Order Thinking. http://academic.pgcc.edu/ wpierce/MCCCTR/Designi ng rubricsassessingt. Diakses tanggal 25 Oktober 2011.

Purwanto, N. 2006. Prinsip-Prinsip dan Teknik Evaluasi Pengajaran. Bandung: Remaja Rosdakarya.

Ratumanan, G.T. 2006. Evaluasi Hasil Belajar yang Relevan dengan Kurikulum Berbasis Kompetensi. Surabaya: Unesa University Press.

Rahmawati, 2012. "Pengembangan Perangkat Pembelajaran Dengan Metode Pembelajaran Penemuan Terbimbing Untuk Melatih Keterampilan Berpikir Kritis Pada Siswa SMP”, Tesis Magister Pendidikan, Universitas Negeri Surabaya.

Rochaminah, S. 2008."Penggunaan Metode Penemuan untuk Meningkatkan Kemampuan Berpikir Kritis Matematis Mahasiswa Keguruan”. Artikel Penelitian. http://www.puslitjaknov.org/data/file/2008/makalah_p eserta/07_Sutji\%20Rochaminah_Penggunaa \%2 0Metode\%20untuk\%meningkatkan\%20kemampuan.p df. Diakses tanggal 6 Januari 2011.

Ruseffendi, E. T. 1988. Pengantar kepada Membantu Guru Mengembangkan Kompetensinya dalam Pendidika Matematika untuk Meningkatkan CBSA. Bandung: Tarsito.

Sastrawijaya, T. A. 2000. Pencemaran Lingkungan. Jakarta: Rineka Cipta.

Schafersman, S.D. 1999. An Introduction to Critical Thinking. (Online) http://ww.freeinquiry.com/critical thinking. html. Diakses tanggal 25 September 2011.

Samsudin. 2001. "Pengembangan Perangkat Pembelajaran Berorientasi pada Pendekatan Penemuan Terbimbing untuk Meningkatkan Kualitas Pendidikan IPA pada Pokok Bahasan Hubungan Antar Makhluk Hidup”. Tesis Magister Pendidikan, Universitas Negeri Surabaya.

Sukajaya, I. K. 2010. “Implementasi Model Problem Based Instruction terhadap Penguasaan Konsep Fisika Hukum Newton dan Kecakapan Berpikir Kritis Siswa”. Tesis Magister Pendidikan, Universitas Negeri Surabaya.

Slameto. 2010. Evaluasi Pendidikan. Jakarta: Bumi Aksara. Soemarwoto, O. 1997. Ekologi, Lingkungan Hidup dan Pembangunan. Jakarta: Jambatan.

Sukarsih. 2006. "Pengaruh Implementasi Pendekatan Sains Teknologi Masyarakat Melalui Tim Hijau Sekolah terhadap ketuntasan Belajar Siswa dalam Pembelajaran Ekosistem di SMP”. Tesis Magister Pendidikan. Universitas Negeri Surabaya.

Thiagarajan, S., Dorothy. S.S. and Melvyn, I.S. 1974.

Instructional Development for Training Teachers of Excptional Children. Indiana: Center for innovation. Trianto, 2007. Model-model Pembelajaran Inovatif Berorientasi Konstruktivistik Surabaya: Prestasi Pustaka.

Triwiyono. 2011."Program Pembelajaran Fisika Menggunakan Metode Eksperimen Terbimbing Untuk Meningkatkan Keterampilan Berpikir Kritis”. Jurnal Pendidikan Fisika Indonesia 7. ISSN: 1693-1246 Juli 2011.pp 80-83. http://journal.unnes.ac.id. Diakses tanggal 10 Oktober 2011.

Undang-undang RI No. 32 Tahun 2009 tentang Perlindungan dan Pengelolaan Lingkungan.

Wardhana, W. A. 2010. Dampak Pencemaran Lingkungan. Yogjakarta: Andi Offset.

Wenno, I.H. 2008. Strategi Belajar Mengajar Sains Berbasis Kontekstual. Yogyakarta: Inti Media.

Woolfolk, A. et all. 2008. Psychology in Education, England. Yamin, M. 2008. Paradigma Pendidikan. 